\title{
New Directions in Biblical Theology
}

\author{
Charles H.H. Scobie
}

[p.4]

\section{Defining 'biblical theology'}

'When 1 use a word,' Humpty Dumpty said in a rather scornful tone, 'it means just what I choose it to mean-neither more nor less.'

(L. Carroll, Through the Looking-Glass, chapter 6)

Students seeking to discover what is meant by 'biblical theology' may be pardoned for concluding that many scholars are as arbitrary as Humpty Dumpty in their use of the term. There appears to be no commonly agreed definition of what constitutes 'biblical theology'. They may well be surprised to find that some appear to hold that biblical theology did not exist before 1787, and equally surprised to discover that others believe that on a strict definition here can be no such thing as a biblical theology today. ${ }^{1}$

What is the problem? Why cannot biblical theology just mean what it says (to come back to Alice)? 'Biblical' comes from the word 'Bible', which comes from the Greek to biblia ('the books'), via the Latin biblia ('the book'), and which in this context means the books of the OT and NT recognized as canonical Scripture by the Christian church. Theology deals with theos, meaning 'God', and by common consent this includes God's relation to the world and to humankind. The ending -logy, from the Greek logos, used in this way means the ordered, systematic, rational, scientific study of a subject. Biblical theology thus ought to mean something like the ordered study of what the Bible has to say about God and his relations to the world and humankind.

The Christian church has always accepted the revelation of God in the Scriptures as in some sense normative for its faith and life. To us it seems obvious that the teaching of the Bible has to be appropriated and applied in each new age. The Bible was written over a one-thousandyear period in times in many ways very different from our own. Theology is the discipline which asks what the Bible has to say to us today.

Some people have used the term 'biblical theology' to mean such a system of Christian doctrine based on the Bible, a 'theology that accords with the Bible' (Ebeling). ${ }^{2}$ Thus Karl Barth's theology could well be described as 'a biblical theology'. This use of the term is really redundant, however, for all forms of Christian theology claim to be in some way based on, or in accord with, the Bible. The theology which the church has to work out in each new age is better designated as 'dogmatic theology' (Barth called his work Church Dogmatics) or 'systematic theology'.

Much more common is the use of 'biblical theology' to mean the theology of the Bible itself, 'the theology contained in the Bible' (Ebeling). What we may not realize, however, and what

\footnotetext{
${ }^{1}$ On the history of biblical theology see Hasel 1975, Hasel 1978, and Reventlow 1986.

${ }^{2}$ Ebeling 1963, p. 79.
} 

1992): 4-8.

we may find hard to understand is that the idea of making a clear separation between what the Bible meant in its original historical context and what it means for Christians today is a relatively modern one; it became possible with the rise of modern historical consciousness and was only clearly enunciated towards the end of the eighteenth century. Prior to that, the teaching of the Bible was not clearly distinguished from the teaching of the church; the one was more or less integrated with the other. Yet it is surely nonsense to hold that the church had no biblical theology before the eighteenth century; I have suggested that the early period was characterized by what may be called an integrated biblical theology.

With the rise of historical consciousness and the development of historical-critical methods the distinction did come to be drawn between the original theology of the Bible (discovered by these historical methods) and the later dogmatic theology of the church. Biblical theology came to be regarded as entirely independent from dogmatics and from later church tradition. This may be called the period of independent biblical theology. Important as its contributions are, this approach has led to an impasse in which we still find ourselves today.

Recent developments have suggested that biblical theology cannot be regarded as a purely historical and descriptive discipline in isolation from the community which accepts the Bible as Scripture. Rather it stands in an intermediate position between historical study of the Bible on the one hand, and dogmatic theology (and related areas) on the other. This approach may be characterized as an intermediate biblical theology.

\section{A brief history ${ }^{3}$}

As the books of the NT were added to those of the OT to form the Scriptures of the Christian church, these books were used by the church in formulating its beliefs and in countering what it considered to be false teachings (e.g. Gnosticism). A writer such as Irenaeus (late second century) certainly employed a form of biblical theology as he sought to understand the relation of unity to diversity within Scripture, the relation of the OT to the NT, and the overall structure of the biblical revelation. But, like the Church Fathers who followed him, he made no distinction between the teaching of Scripture and the 'rule of faith' or teaching of the church.

The most basic problem of biblical theology in any age is that of reconciling the desire for a uniform and consistent set of beliefs with the manifest diversity of the Bible. In the early centuries this problem was often tackled by means of allegory which sought a hidden, spiritual sense behind the literal meaning. This tended to disregard history and find the same theology throughout the whole of Scripture; the danger obviously was that of reading meanings into passages quite contrary to their original significance.

When we come to the Protestant Reformation, the work of its leaders was clearly based on a form of biblical theology. Luther, Calvin and others sought to return to scriptural teaching and to judge later traditions and practices by norms derived from Scripture. They too had to face the problem of unity and diversity; Luther, for example, did this with his dialectic of law and gospel, and his use of 'justification by faith' as an interpretive key (even though it led him to

\footnotetext{
${ }^{3}$ On the history of the interpretation of Scripture see Grant and Tracy 1984.
} 

1992): 4-8.

doubt the canonicity of three or four NT books). Yet even with the Reformers there was no clear distinction between the faith of the Bible and the faith of the church.

In the post-Reformation period the way was prepared for an independent biblical theology by three developments. Firstly, the practice developed within Protestant Orthodoxy of compiling collections of proof texts (dicta probantia), usually accompanied by exegetical comments, in order to demonstrate the biblical basis of Protestant doctrine. The 'proof text' approach has obvious weaknesses but it did turn attention to the content of the Bible. The earliest known use of the term 'biblical theology' refers to a work of this kind published in 1629. Secondly, the revival movement we know as Pietism, reacting against the barrenness of Protestant orthodoxy (though not against orthodox belief), turned to the Bible for spiritual and devotional nourishment. In the eighteenth century several Pietiests published works with 'biblical geology' in the title. Thirdly, a different kind of reaction, that of Rationalism, sought to escape from later church dogmas and discover in the Bible universal and timeless truths in accordance with reason. The five-volume Biblische Theologie (1771-86) by G.T. Zacharia is typical of this approach.

In 1787 G.T. Gabler, on his appointment to the University of Altdorf, gave an inaugural address, the Latin title of which may be rendered as 'An Oration on the Proper Distinction Between Biblical and Dogmatic Theology and the Specific Objectives of

\section{[p.5]}

Each'. Historians down to the present day have seized on this title as embodying the essence of the new approach which was emerging towards the end of the eighteenth century. Biblical theology is to be thought of as an historical and descriptive discipline, quite independent from dogmatic theology. And this certainly was the route taken by many in the nineteenth century. (Recent study has shown that Gabler distinguished 'true biblical theology', which is historical, from 'pure biblical theology', which is an intermediate stage between historical biblical theology and dogmatics. He was deeply concerned about the meaning of the Bible for his day, though he had a strongly rationalist outlook.)

A succession of 'biblical theologies' was published from around 1790 well on into the nineteenth century. The problem was that application of the new historical-critical methods (themselves influenced by the prevailing Rationalism) brought out the diversity of Scripture (especially of the OT $v$. the NT) and emphasized the complex process of historical development through which the Bible came into being. Thus biblical theology began to diverge into OT theology and NT theology, the way being led as early as G.L. Bauer who wrote separate works on the theology of the OT (1796) and of the NT (1800-02).

The historical approach revolutionized the understanding of the Bible, including questions of authorship and date, thus inviting a quite new historical reconstruction. Archaeological discoveries provided a mass of material from the Ancient Near East and the Graeco-Roman world which made the religion of the Bible look less unique. By the end of the nineteenth century OT and NT theology had given way to the study of the history of religion

\footnotetext{
${ }^{4}$ An English translation, along with helpful introduction and comments, will be found in Sandys-Wunsch and Eldredge 1980.
} 

1992): 4-8.

(Religionsgeschichte). This approach is well characterize in W. Wrede's 1897 monograph, 'Concerning the Task and Method of So-called New Testament Theology'. This is available in English translation ${ }^{5}$ and is worth reading if only because its approach is still typical of many academic biblical scholars today. Wrede held that both terms of the expression 'NT theology' are wrong. Since the discipline is purely historical it cannot be limited by the bounds of the canon but must include all relevant literature. Its true subject matter is not theology but early Christian religion which the scholar tries to investigate 'as objectively, correctly and sharply as possible.... How the systematic theologian gets on with its results and deals with them-that is his own affair. Like every other real science, New Testament theology has its goal simply in itself, and is totally indifferent to all dogma and systematic theology. ${ }^{6}$ Here indeed is independent biblical theology!

After the First World War the reaction in dogmatic theology led by Karl Barth had its counterpart in a renewed interest especially in OT theology, with W. Eichrodt's Theology of the Old Testament being perhaps the most impressive of a series of such works. On the NT side the best-known work was R. Bultmann's brilliant if controversial Theology of the New Testament. Important contributions were also made by O. Cullmann in his Christ and Time and Salvation in History. These certainly represent a re-emphasis on theology rather than history of religion, and some have spoken of a 'biblical theology movement', especially in the English-speaking world, which peaked in the 1950s. An analysis of the 'movement' and its inherent weaknesses is provided in B. Childs' Biblical Theology in Crisis (1970), which is required reading for an understanding of the present-day situation. While this movement produced biblical 'word-books' and spoke much of the unity of the Bible, it is significant that it did not produce a single 'biblical theology'.

The 1960s and 1970s saw a movement back to emphasis on diversity and development within the Bible. A purely historical approach was encouraged by the development of numerous 'Departments of Religious Studies' within universities. Biblical theology was seen as dealing with what the Bible 'meant', not what it 'means', though in fact for many not only was biblical theology abandoned, but even OT and NT theology were ruled out of court. At best one could speak of the Priestly theology or the Deuteronomic theology in the OT field, and of Pauline or Johannine theology in the NT.

Somewhat misleadingly, this highly fragmented, historical, descriptive approach could still be labelled by some of its practitioners as 'biblical theology', though it could well be argued that it is strictly neither 'biblical' nor 'theology'. Yet on the other hand if the term was understood in a stricter sense as dealing with OT and NT together, and dealing with the ordered study of the biblical understanding of God and his relation to the world and mankind, many biblical scholars would simply say that such a thing is quite out of the question today. This is the impasse in which biblical scholarship finds itself at the present time.

\footnotetext{
${ }^{5}$ In Morgan 1973, which also has a helpful introduction.

${ }^{6}$ Morgan 1973, p. 69.

${ }^{7}$ This often-quoted distinction originated in Stendahl 1962.
} 


\section{New directions}

Recent years have seen a questioning of some of the basic assumptions of modern biblical study and this has opened up the possibility of new directions in biblical theology.

Academic study of the Bible has tended to separate it from the life of the church. There appears to be a growing awareness that the study of the Bible cannot be separated from the ongoing community which accepts it as canonical Scripture. In the field of literary studies various forms of 'reader-response criticism' have stressed the role of the reader in the interpretation of texts. According to S.E. Fish, ${ }^{8}$ texts have meaning only in the context of an 'interpretive community'; clearly the appropriate interpretive community for the Christian Bible is the Christian church. A growing number of biblical scholars have been speaking of what P.D. Hanson has called 'the responsibility of biblical theology to the community of faith'. W. Wink began his The Bible in Human Transformation (1973) with the startling sentence, 'Historical biblical criticism is bankrupt. ${ }^{, 10}$ Wink does not in fact advocate the abandonment of historical methods; he goes on to explain, 'Biblical criticism is not bankrupt because it has run out of things to say or new ground to explore. It is bankrupt solely because it is incapable of achieving what most of its practitioners considered its purpose to be: so to interpret the Scriptures that the past becomes alive and illumines our present with new possibilities for personal and social transformation.'

This links up with another recent trend, the growing questioning of the role of historical criticism. What is being questioned is not so much the method itself as the use that is made of it. Typically, historical criticism has regarded the biblical text as data from which to reconstruct the history and religion of ancient Israel and the early church. It has looked not so much at the text as through the text to the history which lies behind it. It has tended to regard only the earliest level to which it can penetrate as 'authentic'. For example, many scholars regard the conclusion of the book of Amos, the 'Appendix of Hope' (Am. 9:8c-15), as a later addition which is therefore to be discounted in any study of the theology of Amos. The reference to a future resurrection and judgment in John 5:28-29 is regarded as the work of an 'ecclesiastical redactor' and is irrelevant to the study of Johannine theology with its purely realized eschatology.

Recent reactions against this kind of approach include J.A. Sanders' method of 'canonical criticism', which examines the whole process of transmitting, editing and shaping the biblical material up to and including its final canonical form. ${ }^{11}$ The 'tradition-historical' approach associated especially with the OT scholar H. Gese and the NT scholar P. Stuhlmacher seeks to trace the long and often complex process of the transmission of biblical traditions through the OT, the inter-testamental period and on into the NT without a break; this has been hailed as a new form of biblical theology, but it depends on assumptions which are not accepted by all scholars and raises questions, e.g. regarding where the norm is to be found in Scripture. ${ }^{12}$ Two ongoing series, Overtures to Biblical Theology (Fortress Press) and Biblical Encounters (Abingdon Press), publish studies of biblical themes which, while not ignoring diversity, tend to stress continuity, and also relate the themes to contemporary concerns.

\footnotetext{
${ }^{8}$ See Fish 1980, pp. 171-172.

${ }^{9}$ See Hanson 1980.

${ }^{10}$ Wink 1973 , p. 1 . The following quotation is from p. 2.

${ }^{11}$ See Sanders 1984.

${ }^{12}$ See Reventlow 1986, pp. 149-154, and Hasel 1982, pp. 63-67.
} 

1992): 4-8.

The claim of historical criticism to present an objective, neutral descriptive approach to the Bible is increasingly questioned. Modern hermeneutical theory, ${ }^{13}$ especially as influenced by H.-G. Gadamer, recognizes that there can be no interpretation of texts without presuppositions. Not that such presuppositions go unquestioned; the interpreter must remain open to the text and participate in a 'fusion of the horizons', i.e. the horizon of the text and the horizon of the interpreter. The underlying presuppositions of much historical criticism have been rationalistic and positivistic, so that some of the most central assertions of the texts themselves - the presence and activity of God in nature and in history-have been set aside. It is in reaction to this that scholars such as P. Stuhlmacher have called for a 'hermeneutics of consent to the biblical texts' which will be marked by 'a willingness to open ourselves anew to the claim of tradition, of the present, and of transcendence'. ${ }^{14}$

Yet another significant trend is a new willingness to focus on the final, canonical form of the biblical text. This is generally

typical of the renewed literary interest in the Bible (which can otherwise be marked by considerable diversity). Literary critics tend to look at the text as it stands, rather than through the text to the history that lies behind it. While some focus on relatively small textual units, the literary critic Northrop Frye looks at the entire Bible as a literary whole. What impresses him is the continuity to be found in the Bible which he characterizes as a sequence or dialectical progression consisting of seven main phases which run from creation to apocalypse. Frye is well aware of the findings of historical criticism, but finds them irrelevant to his purpose which is to study Scripture in the form in which it has exerted a tremendous influence over Western culture. Thus although critical scholars hold that Genesis 1 comes from the latest of the four Pentateuchal sources, 'A genuine higher criticism', Frye remarks, 'would observe that this account of creation stands at the beginning of Genesis, despite its late date, because it belongs at the beginning of Genesis'! Frye holds that while the Bible is 'certainly the end product of along and complex editorial process, the end product needs to be examined in its own right'. 15

Most significant of all for charting a new direction for biblical theology has been the advocacy of a 'canonical approach' associated primarily with the work of B.S. Childs. First enunciated in his Biblical Theology in Crisis, then worked out in a number of subsequent books and articles, Childs argues that 'the canon of the Christian church is the most appropriate context from which to do biblical theology'. ${ }^{16}$ Childs does not reject historical criticism, but seeks to go beyond it by focusing on the form of the text which has been accepted as canonical by the church. To date, the canonical approach has been applied by Childs in a commentary on Exodus, in 'Introductions' to the OT and NT, and most important) in his Old Testament Theology in a Canonical Context, but not to a 'biblical theology' which embraces both Testaments together.

\footnotetext{
${ }^{13}$ For a helpful introduction see Maddox 1985.

${ }^{14}$ Stuhlmacher 1977, pp. 83, 85.

${ }^{15}$ Frye 1981, p. xvii.

${ }^{16}$ Childs 1970, p. 99.
} 

1992): 4-8.

These trends have to be carefully and critically evaluated, but they do demonstrate a certain convergence of opinion and point towards a new direction for biblical theology.

\section{An intermediate biblical theology}

There can be no return to the situation of an integrated biblical theology which existed before the rise of the modern historical approach. Yet the pursuit of a totally independent biblical theology has led to an impasse. What holds promise is an approach which sees biblical theology as a bridge discipline standing between historical (and literary) study of Scripture on the one hand, and the use of Scripture by the church in dogmatic theology and related disciplines on the other.

Historical-critical study of the Bible still has an important role to play. The books of the Bible must be interpreted against their historical background; questions of authorship, date, destination, purpose and so on must be based on a critical assessment of the evidence; and study of individual books and authors must be based on painstaking exegesis which aims to understand the meaning of the text in its original setting. But the limits of historical criticism must be kept in mind. The method can generally yield only possible or probable, not certain, results. No historian is free from presuppositions; those of the biblical critic require careful scrutiny. It is not just the (often hypothetical) original form of a tradition that is 'authentic'; all levels of Scripture must be given due weight through to the final edited form.

Literary study of the Bible can provide an alternate vantage point from which to view the Bible as a whole. Especially where it deals with Scripture in its final canonical form, it can shed light on the shape and structure of the Bible, and on its essential continuity. But care must be taken to ensure that the text is not understood in a way inconsistent with the original historical meaning.

An intermediate biblical theology will assume and accept the findings of the historical and literary approaches, but will seek to go beyond them and move from analysis to synthesis. It will still be basically concerned with 'the horizon of the text', and will attempt to provide an overview and interpretation of the shape and structure of the Bible as a whole. It will seek the unity and continuity of Scripture, but without sacrificing the richness of its diversity. It will focus not on exegetical details but on the broad interrelationships between the major themes of the Bible, and above all on the interrelationship between the Testaments.

It is clear that this cannot be done in a 'neutral' or 'objective' fashion. An intermediate biblical theology is inevitably part of the interpretive process, and its presuppositions will be those of the interpretive community, including belief that the Bible conveys a divine revelation, that the Word of God in Scripture constitutes the norm of Christian faith and life, and that all the varied material of the OT and NT can in some way be related to the plan and purpose of the one God of the whole Bible. Such a biblical theology lies somewhere between what the Bible 'meant' and what it 'means'.

An intermediate biblical theology provides a bridge to dogmatic theology, the discipline which seeks to apply the Word of God in each new day and age. Dogmatic theology in turn ought to illuminate and direct every aspect of the church's life: it must form a bridge to the church's worship, preaching, teaching, devotion, ethical reflection and Christian action. The 

1992): 4-8.

biblical material synthesized by biblical theology constitutes the norm which has to be correlated with the situation faced by the church today. While the contemporary Christian community is the true interpreter of Scripture, it is equally true that the community must constantly scrutinize its faith and life in the light of the Word of God in Scripture. Contemporary theological concerns (e.g. ecology, feminism, human rights) do not determine or dictate the conclusions of biblical theology, but they can prompt biblical scholars to reassess the scriptural evidence which may have been obscured or distorted by later nonbiblical prejudices and presuppositions.

\section{Biblical theology is canonical theology}

It has been proposed above that 'the canonical approach' provides the most promising way forward. Biblical theology, it may be suggested, is canonical theology in five senses.

Firstly, biblical theology is to be limited to the canonical books of the church's Scripture. However important they may be for the study of the history of religion, the inter-testamental literature and the Apostolic Fathers are not part of the scriptural material which the church recognizes as constituting the norm of its faith and life. This of course does not deny that there may be much of value and of truth in these and other non-biblical works, only that biblical theology is concerned with those books which contain the norm by which value and truth are to be evaluated.

Secondly, biblical theology is to be based on the entire canon, consisting of both OT and NT. Much recent German discussion has focused on the question of 'eine gesamtbiblische Theologie', an all-biblical theology'. This means above all seeking to do justice to the OT, not just seeing it as a quarry of proof texts or, in terms of 'law', as a foil for the gospel. 'The church', contends S. Terrien, 'needs to be cleansed of its traditional Marcionism-a theological form of anti-Semitism-which has been revived in modern times by Schleiermacher, Harnack and Bultmann, among others. ${ }^{17}$

Thirdly, biblical theology is to be based on the Christian form of the canon. In the Hebrew order of Torah-Former Prophets-Latter Prophets-Writings the emphasis falls on Torah as God's supreme revelation. The Christian order (based on the Septuagint for the OT) is Torah-History-Writings-Prophets-Gospels-History-Epistles-Revelation. In this order the gospels are central. The position of the prophets makes the OT open-ended, looking forward to the Christ event, while the books following the gospels look back to it. A more difficult question is the status of the apocryphal/deuterocanonical books excluded from the Hebrew Scriptures but accepted by major Christian traditions. Whatever view is held of their inspiration a case can be made for taking them into account in a biblical theology as a link between the Testaments.

Fourthly, an intermediate biblical theology will be based primarily on the final canonical form of the text. The word 'primarily' is important, for the historical-critical approach remains a preparatory stage of biblical theology and a safeguard against unwarranted interpretations. But what the church has always accepted as canonical is the final form of the text. It did not canonize J, E, D or P. What is significant about the book of Amos is that it was not accepted

\footnotetext{
${ }^{17}$ Terrien 1980, p. 75.
} 

1992): 4-8.

into the canon without 'The Appendix of Hope'; the result is that in Amos, as in all the prophets, however much the emphasis may vary, there is a dialectic of judgment and mercy. Similarly the significant thing about John's gospel is that it was only accepted by the church in the 'ecclesiastically redacted' form (if that is what it is); the result is that John, like the rest of the NT, however much the emphasis may vary, presents a form of inaugurated eschatology.

[p.7]

Finally, a canonical biblical theology will attempt to deal with the full range of the canonical materials. In particular it will resist the temptation to adopt 'a canon within the canon' which gives priority to certain themes, passages or books to the exclusion of others. This is a short cut to finding unity in the Bible which must be avoided. For example, the Pauline epistles are of fundamental importance for biblical theology, but the Epistle of James is part of the canon also and must be given its place in a fully canonical biblical theology.

\section{A structured biblical theology}

What form will such a biblical theology take in practice? There are those who see biblical theology primarily as a dimension of exegesis, or of the study of individual books or authors, or of particular biblical themes. Certainly this can be part of biblical theology provided the passages, books or authors under study are placed in their total biblical context. The tracing of themes through both OT and NT, already referred to, is certainly an important part of biblical theology. But the question must be raised as to whether such fragmented study is sufficient. The study of biblical themes in isolation raises the question of how the various biblical themes are interrelated. Studies which span OT and NT raise the question of the interrelationship of the Testaments. Such questions cannot be answered without some view of the structure of the biblical revelation as a whole.

This raises the question of whether the time has come to attempt again not just 'doing biblical theology' but writing 'a biblical theology'. It will be recalled that volumes of biblical theology were produced in the eighteenth century and the first half of the nineteenth century before the enterprise diverged into separate OT and NT theologies. After about a century in which virtually no major 'biblical theology' appeared (one possible exception is M. Burrows' An Outline of Biblical Theology, 1946), the uestion of such an undertaking is again the subject of lively discussion. In addition to the programmatic essays which have appeared in recent years, the American OT scholar S. Terrien has let the way with his work The Elusive Presence: The Heart of Biblical Theology, published in 1978, which may be claimed as the first major scholarly attempt to write a truly biblical theology encompassing both OT and NT in over a century. It has been followed by a work similar in scope by the German scholar H. Seebass, Der Gott derganzen Bibel ('The God the Whole Bible'), published in 1982.

Such an undertaking raises the very basic question of the appropriate structure for a biblical theology. Historically, all OT and NT theologies, and the much smaller number of biblical theologies, have adopted some form of structure which has to a considerable degree affected the way in which the biblical material is presented. Three types of structure may be broadly distinguished. 

1992): 4-8.

The first may be classified as a systematic structure. All the earliest biblical theologies followed the type of outline employed in the Collegia Biblica of Protestant orthodoxy. That is, the material was arranged under the headings normally employed by dogmatic theology. Such an approach continued to be used in the nineteenth century, sometimes in simplified form, but generally following some such sequence as God, Man, Sin, Christ, Salvation, Church, sacraments, and so on. It has persisted into the twentieth century in biblical theology (Burrows), OT theology (Köhler, Baab, Heinisch, Jacob) and NT theology (Grant, Richardson, Schelkle). Nevertheless it has come under severe criticism as imposing doctrinal categories which are foreign to biblical thought, and as excluding certain major biblical themes.

The advent of historical criticism prompted a totally different method of ordering the material: the Bible began to look less and less like a text book of systematic theology and more and more like a history book, so an historical outline was adopted which traced the development of biblical faith in a chronological sequence which was increasingly the product of scholarly reconstruction. This scheme is particularly typical of the History of Religions approach and is still widely used in many standard works and text books. It is well suited to the type of historical study which must precede biblical theology, but hardly does justice to the theology of the Bible. Hybrid forms of structure can be found: a good example is D. Guthrie's New Testament Theology, which opts for a basic systematic structure (God, Man, Christology, the Mission of Christ, the Holy Spirit, the Christian Life, the Church, the Future, Ethics, and Scripture), but within each section and sub-section takes a historical approach, reviewing each segment of the NT in turn.

Dissatisfaction with both these structures led to a third approach which may be characterized as thematic. While there were some earlier precedents, the first notable theology of this type was W. Eichrodt's Theology of the Old Testament, which took the theme of 'covenant' as its organizing principle, and arranged the main topics of the OT under the tree major headings of 'God and Nation', 'God and World' and 'God and Men'. This sparked off a long debate on the appropriate 'centre' of an OT theology, with numerous alternative suggestions being made; to a lesser extent there has been a similar debate in NT studies. ${ }^{18}$ Others feel that no one theme can possibly do justice to the richness and diversity of either OT or NT. This is even more so the case if the question is raised regarding one theme which could form the basis of a truly biblical theology. Suggestions here include 'covenant', 'the Kingdom of God' and salvation history'; Terrieri's The Elusive Presence takes as its controlling theme 'the presence of God'.

These and other suggestions invite serious criticism and it is difficult to understand the obsession with finding one single theme or centre on which to base a biblical theology. On the other hand, a multiple theme approach holds much promise. Two examples may be cited. E.A. Martens' Plot and Purpose in the Old Testament identifies four key interrelated themes: salvation/deliverance, the covenant community, knowledge/experience of God, and land. These are traced through the OT with a few suggestions as to how the same themes might be followed through the NT. W. Dumbrell's The End of the Beginning: Rev. 21-22 and the Old Testament is not a fully-fledged biblical theology, but it does deal with five related themes found in the last two chapters of the Bible: the new Jerusalem, the new temple, the new

\footnotetext{
${ }^{18}$ See Hasel 1975, ch. IV, and Hasel 1978, ch. III.
} 

1992): 4-8.

covenant, the new Israel, and the new creation. The development of these themes is traced through OT, gospels and epistles and back to Revelation, thus showing how 'the entire Bible is moving, growing according to a common purpose and towards a common goal'. ${ }^{19}$ A multithematic approach ensures, so far as is humanly possible, that the structure arises from the biblical material itself rather than being imposed from the outside. It allows full scope for dealing with topics-for example the theme of Wisdom-which tend to be seriously underrepresented, if not excluded, from more traditional schemes. It is consistent with a 'dialectical' approach which recognizes the bi-polar nature of many key biblical themes. For example, the emphasis on 'salvation-history' and on 'the God who acts' has to be balanced by an emphasis on creation theology (which has received a lot of recent attention). Terrien's The Elusive Presence illustrates the possibilities of this approach with its dialectic of the divine self-disclosure and self-concealment, of a theology of the 'name' and a theology of 'glory', of the aesthetics of the mystical eye and the demands of the ethical ear, and so on.

For a full-scale biblical theology it would be desirable to identify a limited number of major themes; in fact, when the numerous suggestions which have been made for a 'centre' are examined they tend to fall into about four major groups. Round these appropriate minor themes could be grouped. The various themes must be traced through OT and NT and a satisfactory method found of correlating the OT and NT material. This obviously raises many complex problems and limitations of space preclude their discussion here. Elsewhere I have made tentative suggestions regarding a possible overall structure for a biblical theology. ${ }^{20}$

\section{The challenge of biblical theology}

The kind of enterprise which has been barely hinted at here would obviously constitute a colossal challenge to biblical scholarship, and even many who do not oppose it in theory hold it to be impossible in practice.

Certainly it could only come about through the co-operation of OT and NT scholars, which would break down the unhealthy over-specialization and compartmentalization that characterizes much biblical scholarship today. It would equally call for cooperation between biblical scholars and systematic theologians. If biblical theology is to be thought of as a bridge discipline then it is a bridge which must carry heavy traffic-travelling in both directions. And it must be a truly ecumenical enterprise in which scholars of different denominations and confessional backgrounds co-operate. Liberal Protestants no longer dominate the field. The entry of Roman Catholics into the mainstream of biblical scholarship, and the growing scholarly contribution from conservative evangelicals, hold out exciting possibilities.

\section{[p.7]}

Though for long the Cinderella of the theological disciplines, and though still subject to violent attack by many academic biblical scholars, there are signs that biblical theology may be about to come back into its own.

\footnotetext{
${ }^{19}$ Dumbrell 1985. Quotation from Introduction (no page number).

${ }^{20}$ Scobie $1991 \mathrm{~b}$.
} 
Charles H.H. Scobie, "New Directions in Biblical Theology," Themelios 17.2 (January/February 1992): 4-8.

\section{Bibliography}

Burrows, M., 1946: An Outline of Biblical Theology (Philadelphia: Westminster).

Childs, B.S., 1970: Biblical Theology in Crisis (Philadelphia: Westminster).

Childs, B.S., 1985: Old Testament Theology in a Canonical Context (London: SCM).

Dumbrell, W., 1985: The End of the Beginning: Rev. 21-22 and the Old Testament (Grand Rapids: Baker).

Ebeling, G., 1963: 'The Meaning of 'Biblical Theology"', in Word and Faith (Philadelphia: Fortress), pp. 79-97.

Eichrodt, W., 1933-9: Theologie des Alten Testaments (Leipzig: Hinrichs) (ET, 1961-5: Theology of the Old Testament, London: SCM).

Fish, S.E., 1980: Is There A Text In This Class? The Authority of Interpretive Communities (Cambridge: Harvard University Press).

Frye, N., 1981: The Great Code: The Bible and Literature (Toronto: Academic Press).

Grant, R.M. and Tracy, D.,1984: A Short History of the Interpretation of the Bible, rev. ed. (Philadelphia: Fortress).

Guthrie, D., 1981: New Testament Theology (Leicester: Inter-Varsity Press).

Hanson, P.D., 1980: 'The Responsibility of Biblical Theology to the Community of Faith', TT 37, pp. 39-50.

Hasel, G.F., 1975: Old Testament Theology: Basic Issues in the Current Debate, rev. ed. (Grand Rapids: Eerdmans).

Hasel, G.F., 1978: New Testament Theology: Basic Issues in the Current Debate (Grand Rapids: Eerdmans).

Hasel, G.F., 1982: 'Biblical Theology: Then, Now and Tomorrow', HBT 4:1, pp. 61-93.

Maddox, R.L., 1985: 'Contemporary Hermeneutic Philosophy and Theological Studies', RS 21, pp. 517-529.

Martens, E.A., 1981: Plot and Purpose in the Old Testament (Leicester: InterVarsity Press).

Morgan, R., 1973: The Nature of New Testament Theology (London: SCM).

Reventlow, H.G., 1986: Problems of Biblical Theology in the Twentieth Century (Philadelphia: Fortress).

Sanders, J.A., 1984: Canon and Community: A Guide to Canonical Criticism (Philadelphia: Fortress).

Sandys-Wunsch, J. and Eldredge, L.,1980: 'J.P. Gabler and the Distinction Between Biblical and Dogmatic Theology: Translation, Commentary and Discussion of His Originality’, SJT 33, pp. 133-158.

Scobie, C.H.H., 1991a: 'The Challenge of Biblical Theology', TB 42.1, pp. 31-61.

Scobie, C.H.H., 19916: 'The Structure of Biblical Theology', TB 42.2, pp. 163-194.

Seebass, H., 1982: Der Gott derganzen Bibel: Biblische Theologie zur Orientierung im Glauben (Freiburg/Basel/Vienna: Herder).

Stendahl, K., 1962: 'Biblical Theology, Contemporary', in The Interpreter's Dictionary of the Bible, vol. I (New York: Abingdon), pp. 418-432.

Stuhlmacher, P., 1977: Historical Criticism and Theological Interpretation of Scripture (Philadelphia: Fortress).

Terrien, S., 1978: The Elusive Presence: The Heart of Biblical Theology (San Francisco: Harper \& Row).

Terrien, S., 1980: 'The Pursuit of a Theme', in Frizzell, L.E. (ed.), God and His Temple: Reflections on Professor Samuel Terrien's The Elusive Presence: Toward a New Biblical Theology (South Orange, N.J.: Seton Hall University), pp. 72-80.

Wink, W., 1973: The Bible in Human Transformation: Toward a New Paradigm for Biblical Study (Philadelphia: Fortress). 
Charles H.H. Scobie, "New Directions in Biblical Theology," Themelios 17.2 (January/February 1992): 4-8.

(C) 1992 Charles H.H. Scobie. Reproduced by permission of the author. Readers interested in this subject are referred to Dr Scobie's recent book: An Approach to Biblical Theology. Grand Rapids: Eerdmans, 2002. Pbk. ISBN: 0802849504. pp.976.

Prepared for the Web in October 2006 by Robert I. Bradshaw.

http://www.theologicalstudies.org.uk/ 